\title{
Yaratıcı Drama Yöntemiyle Yapılan Grup Çalışmasının Cinsiyet Ayrımcılığına Etkisi
}

\author{
Hüseyin ALTINOVA ${ }^{1}$ \\ Ankara Üniversitesi
}

\author{
Hülya ALTINIŞIK ${ }^{2}$ \\ Milli Eğitim Bakanlığ
}

\begin{abstract}
$\ddot{O}_{z e t}$
Bu araştırmada, yaratıcı drama yönteminin cinsiyet ayrımcıliğına etkisi incelenmiştir. Araştırma, Ankara ili, Çankaya ilçesinde bir ilköğretim okulunda çocukları öğrenim gören annelerle yürütülmüşü̈r. Araştırmaya 16 deney, 16 kontrol grubu üyesi olmak üzere toplam 32 kadın katılmıştır. Araştırmada veri toplama aracı olarak Toplumsal Cinsiyet Algısı Ölçeği ve soru formu kullanılmıştır. Araştırma, kontrol gruplu ön test-son test modelinin kullanıldiğ deneysel bir çalışmadır. Deney grubuna araştırmacılar tarafindan hazırlanan "Yaratıcı Drama Programı" 12 oturum olarak uygulanmıştır. Her bir oturum, yaklaşık 120 dakika olarak gerçekleştirilmiştir. Kontrol grubuna yönelik olarak araştırmacılar tarafindan herhangi bir uygulama yapılmamıştır. Araştırmada nicel ve nitel veriler elde edilmiştir. Nicel verilerin analizinde, deney ve kontrol grubunun ön test puanları arasındaki eşitliği, son test puanları arasındaki farklılığl görebilmek için "t testi" kullanılmıştır. Deney ve kontrol grubunun ön test-son test puanları arasındaki farkı bulabilmek için tekrarlı ölçümlerde varyans analizi kullanılmıştır. Deney ve kontrol gruplarından elde edilen sonuçlara göre, deney grubundakileri toplumsal cinsiyet algı düzeylerinin arttı̆̆ görülmüşı̈̈r.
\end{abstract}

Anahtar Sözcükler: Yaratıcı drama, cinsiyet ayrımcılı̆̆l, toplumsal cinsiyet, toplumsal cinsiyet algısl, yetişkin ĕgitimi

\section{Abstract}

In this research, the effect of creative drama on gender apartheid is studied. The research is conducted with the parents of students of Ahmet Andiçen Primary School which is located in district of Çankaya in Ankara. 32 women participate in the research. There are 16 women in experimental gruop and 16 women in control group. As a data collection tool Gender Perception Scale and questionnaire are used. The research is an experimental study which uses pretestposttest design on control group. "Creative Drama Program" which is prepared by researchers is conducted for 12 weeks on experimental gruop. Each session takes 120 minutes. No work is done on control group by reseachers. Quantitative data is collected. In order to find the equality of experimental and control group's pretest score and differance between posttest scores, $t$ test is used. In order to find the differance between pretest and posttest scores of experimental and control group, variance analysis is used in panel scaling. According to results from experimental and control group, it is found out that gender perception level of experimental group increased.

Keywords: Creative drama, gender apartheid, gender, gender perception, adult education

1 Öğr. Gör. Ankara Üniversitesi Sağllk Bilimleri Fakültesi Sosyal Hizmet Bölümü, e-posta : altinova2012@gmail.com

2 Psikolojik Danışman ve Rehber Öğretmen. MEB 


\section{Giriş}

Ayırımcılık, bir sosyal gruba ya da grup üyelerine, grubun bir parçası olmaları nedeniyle uygulanan negatif eylem olarak tanımlanmaktadır (Zanden, 1993; Jones, 2002). Cinsiyet ayırımcılığı da genel anlamda bireylere cinsiyetlerinden dolayı toplumda adaletsiz bir şekilde davranılmasıdır (Gender Discrimination), Bu anlamda, cinsiyet ayrımcılı̆̆ haklarından tümüyle yararlanmasını engelleyen sosyal açıdan yapılandırılmış cinsiyet rolleri ve normlarına dayalı olarak herhangi bir ayırıma, dışlanma ya da kısıtlamaya maruz kalmasıdır (Gender and Reproducti ve Rights, www.who.int). Cinsiyet eşitsizliği; güç, prestij ve mülkiyet dağılımı bireysel meziyetlere değil, cinsiyet esasına dayandırıldığında ortaya çıkmakta (Parrillo, 2002) ve bir cinsin diğer cins üzerinde baskın ya da diğerine göre üstün olduğu inancına dayanan bir ideoloji olan seksizm aracılı̆̆ıyla açıklanmaktadır (Sullivan, 2003). Kadınlara ve erkeklere yönelik belirgin olumsuz eylemleri ifade eden cinsiyet ayırımcılığının (Yoder, 2003; Martin, 2006) değiştirilmesinin zor olduğu, kavramın çoğunlukla kadın cinsine yönelik ayırımcılık olarak karşılık bulduğu ve kadınların ayırımcılıkla mücadelede sosyal statülerini geliştirme şansına yeterince sahip olmadıkları belirtilmektedir (Sullivan, 2003).

1981'de yürürlüğe giren ve Türkiye'nin 1985'te imzaladığı CEDAW'ın birinci maddesinde, kadınlara karşı ayrımcılık şöyle tanımlanmıştır: “...kadınlara karşı ayrımcılık terimi erkeklerle kadınların eşitliği temeli üzerinde ve medeni durumlarına bakılmaksızın, siyasal, ekonomik, toplumsal, kültürel, kişiselya da başka bir alanda, kadınların insan hakları ve temelözgürlüklerinin tanınmasını bu hak ve özgürlükleri kullanmalarını ve bunlardan yararlanmalarını zedelemek ya da kaldırmak amacıyla cinsiyet temeli üzerine yapılan herhangi bir ayrım, dışlama ya da kisitlama anlamına gelir (Arat,1996).

Cinsiyet ayırımcılığı, doğrudan ve dolaylı cinsiyet ayırımcılığı olmak üzere iki biçimde ortaya çıkmaktadır. Doğrudan cinsiyet ayırımcılı̆̆ bir erkeğe davrandığı ya da davranacağından daha olumsuz davranması veya daha az olumlu davranmasıdır. Dolaylı cinsiyet ayırımcıllı̆̆ ise, biçimsel olarak eşitlikçi gözüken davranış veya uygulamaların sonradan kadın üzerinde ayırımcı etkiler yaratmasıdır (Acar, 2004: 216).

Dünyanın hemen her yerinde kadına yönelik cinsiyet ayrımcılığı, farklı düzeylerde de olsa devam etmektedir. Gelişmiş ve demokratik ülkelerde bile örgütlü mücadelelerle kazanılmış haklara karşın kadınlar ekonomik, sosyal, siyasal ve kültürel kaynaklardan, sağlık ve eğitim gibi hizmetlerden eşit ölçüde yararlanamamaktadır. Karar alma süreçlerine erkeklerle eşit düzeyde katılamamaktadırlar.

Cinsiyet ayrımcılığının sonuçlarını, etkilerini değerlendirdiğimizde kadınların, eğitim, sağlık ve istihdam olanakları bakımından hemen hemen her ülkede erkeklerin gerisinde olduğu bilinmektedir (Lopez-Claros ve Zahidi, 2005). Kadın, daha çok karşılıksız aile işlerinde ve erkeğin üretime katılmasına destek olma rolünü üstlenmektedir. Kadın ve erkeğin toplumsal sorumlulukları, toplumdaki yerleri daha çok cinsiyete göre şekillenmektedir (Arslan, 2000). Kadınların günlük yaşam faaliyetlerine tam ve özgür bir şekilde katılma olanağından yoksun olmalarına neden olan cinsiyet ayırımcılığının kapsamına karar mekanizmalarına katılamama, kamusal olanaklardan yararlanamama, sağlıksız koşullarda yaşama, uygun konut sahibi olamama, çalışma yaşamında engellerle karşılaşma, işyerinde taciz ya da haksızlığa uğrama ile sendikaya üye olamama ve sendikal faaliyetlere katılamama gibi çeşitli konular girmektedir (Human Rightsand Equal Opportunity Commision, 2006: 2). 
Cinsiyet ayrımcılığın temelinde toplumsal cinsiyet olgusu vardır. Toplumsal cinsiyet bakış açısı kadına yönelik cinsiyet ayrımcılığını olumsuz etkilemektedir. Toplumsallaşmanın ilk öğrenildiği ailelerde kız ve erkek çocuklara cinsiyet kaynaklı roller, beklentiler, kalıp yargılar açık ya da üstü örtülü bir şekilde sunulur, benimsetilir. Bu iletiler yoluyla çocuklar geleneksel cinsiyet rollerine uygun davranışlar geliştirmeye yöneltilir. Bununla birlikte de kadına ve erkeğe cinsiyet kaynaklı uygun başarı ölçütleri ve sınırları sunulur, hissettirilir.

Hablemitoğlu'na (2006) göre cinsiyet ayrımcılığının bir diğer sonucu da toplumsal cinsiyete dayalı şiddet olarak karşımıza çıkar. Kadının toplum tarafından kabul edilen rolleri ile kadına yönelik şiddet arasında bağlantısı olduğu görülmektedir. Bu bağın toplumsal cinsiyet özellikleri ile de doğrudan ilişkisi vardır. Kadınlar gerek fiziksel gerekse ekonomik açıdan yetersiz olduklarından buna karşı koyamazlar. Erkekler ise toplumsal cinsiyet rollerinin gereği olarak kadın üzerinde hâkimiyet kurma, gücünü ortaya koyabilme gibi nedenlerle kadına şiddete başvurmaktadırlar Toplumsal cinsiyete dayalı şiddet önemli bir kamu düzeni sorunu ve yaygın bir insan hakları ihlalidir (Hablemitoğlu, 2006).

Toplumsal cinsiyet, kadını kültürel yönden daha az değerli kılmaktadır. Türkiye'nin Doğu ve Güneydoğu bölgesinde yapılan bir araştırmaya göre kadınlar eşlerinden izin almadan hastaneye gidememekte, erkek doktorlara muayene olamamakta, aile planlaması ve bunun gibi birçok sağlık hizmetlerinden yeterince yararlanamamaktadır. Bu bölgede yaşayan erkeklerin \%60.2'si, “erkekler kadınlardan daha akıllıdır" ve \%56.7'si "eşine itaat etmeyen kadını kocasının dövmeye hakkı vardır” yargısını onayladığı belirtilmektedir (Kitiş ve Bilgici, 2007). Cinsiyet ayrımcılığı konusunda tüm dünyada uluslararası bir bilinçlenme süreci başlamış olmasına rağmen, ülkeler hâlâ nüfuslarının yarısını teşkil eden kadınlara karşı ayrımcılık yapmaktadırlar. Cinsiyet Ayrımcılığı Bürosu raporunda, insanların temel hakları kullanmasının ve firsatlardan yaralanmasının cinsiyete göre değişmemesi gerektiğini belirtmiştir (Lockwood, 2004, Goodman ve Blum 2003).

Cinsiyete dayalı ayrımcılık, aile içinde başlamaktadır. Kültürel değerler ile de kız ve erkek çocuklar farklı yönlendirilerek sonuçta toplumsal cinsiyet eşitsizliğine onay veren kadınlar ve erkekler yetiştirilmektedir. Toplumun kadına biçtiği rol ve beklentiler, eğitim, evlilik ve çalışma gibi hayatını etkileyecek konularda karar verme ve kararlarını uygulamalarını büyük ölçüde engellemektedir (Arslan, 2003; Demirbilek, 2007; Eren, 2005; Hablemitoğlu, 2005; Markham, 1999; Sever, 2005).

Kadınlar, tarih boyunca cinsiyet ayırımcılığı ve eşitsizliklerle karşı karşıya kalmışlardır. Erkeklerden daha düşük statüde görülmüşler ve erkeklere nazaran daha az hak ve şansa sahip olmuşlardır. Birçok ülkede eşitliğe yönelik gelişmeler kaydedilmesine rağmen, kadınlar hâlâ ayrımcılığa maruz kalabilmekte, cinsel istismar ve aile içi şiddete uğrayabilmektedirler. Kuşkusuz, bunda geleneksel cinsiyet rollerinin ve bu rollerin öğrenildiği sosyalleşme sürecinin etkisi büyüktür. Esen (2002)'in belirttiği gibi cinsiyetçi kalıp yargıların yeniden üretilerek pekiştirilmesi, okul toplumsallaşmasından önce aile, yaşıt grupları, kitle iletişim araçları aracılığıyla başlamaktadır. Dolayısıyla bu cinsiyet ayrımcılığının önlenmesine öncelikle aileden başlanmalıdır. Aile içindeki cinsiyet ayrımı eğitimde cinsiyet ayrımına yansımakta bu da mesleki cinsiyet ayrımına, mesleki cinsiyet ayrımı iş yaşamındaki cinsiyet ayrımına, o da evlilik hayatındaki cinsiyet ayrımına yansıma şeklinde kısır döngü şeklinde gidebilmektedir. 
Ailelerin, kardeşlerin, akrabaların ya da arkadaşların kız ve erkek çocuğa ilişkin görüşleri, planları ve beklentileri kuşaktan kuşağa geçer ve onların her iki cinsiyet için beklentilere uygun davranmasını sağlar. Örneğin kızlar hanım hanımcık olmalı, erkeklerse güçlü ve cesur. Kadınların ev işi yapmalarının nedeni onların kadın olmaları değil küçüklüklerinden beri bu tür işleri yapmayı öğrendikleri içindir. Bu anlayış ve modeller kuşaktan kuşağa öyle bir kalıpla geçer ki kız çocuklar annelerine, erkek çocuklar da babalarına benzer (Millî Eğitim Bakanlığı).

Aile tutumlarındaki yanlış yaklaşımlar çocukları cinsiyet ayrımcıllı̆ı̆ına maruz bırakmaktadır. Evde bebeklikten başlayarak, giydirilen renkler, alınan oyuncaklar, önerilen ev içi iş bölümü, davranışa dönük beklentiler (nelerin pekiştirilip nelerin söndürüldüğü), vb. ile örgün eğitim sistemi içinde, ders kitaplarından öğretmenin sınıf içi tutumuna kadar pek çok yolla toplumsal cinsiyete karşı önyargılar sürekli pekiştirilmektedir.

Ünal (2003)'a göre okul ortamı, toplumsal cinsiyet ilişkileri dikkate alındığında, erkek iktidarının sürdüğü bir toplumsal alan olma özelliği göstermektedir. Bu yönüyle okul hem egemen değerlerin yeniden üretildiği bir ortam hem de diğer tüm toplumsal alanlar gibi kadınlar için bir siyasal mücadele alanıdır. Cinsiyetçilikle mücadele erkek iktidarına karşı yürütülen ve cinsler arası eşitliği hedefleyen bir mücadeledir. Bunun için de eğitim sektörü içinde olan veliler için de bu mücadelenin verilmesi gerekmektedir. Cinsiyetçilikle mücadele, ataerkil yapılanmanın diğer tüm kurumlarında olduğu gibi okullarda da sürmelidir. Bu araştırmanın çıkış noktası, kadınları eğitim ve yaşantı yoluyla güçlendirerek kadınlarda toplumsal cinsiyet kavramı hakkında farkındalık yaratmak ve bilinçlendirmektir. Bilinçlendirme çabaları ile kadınların sadece anne ya da eş olarak değil, birer vatandaş olarak görev ve ihtiyaçlarının farkına varmaları hedeflenir. Kadınlara toplumsal cinsiyet rolleri hakkında bilinç kazandırıldı̆̆ takdirde, kendi haklarına sahip çıkabilecekleri, katılımcı olacakları, aile içinde iletişimlerinin daha iyi olacağı, toplumsal kalıp yargılarını bileceği ve bu yargıları değiştirmek için çaba harcayacakları düşünülebilir.

$\mathrm{Bu}$ amaçla velilerin cinsiyet rolü algısını geliştirmek için bir grup çalışması planlanmıştır. Grup çalışması yöntemi olarak yaratııı drama seçilmiştir. Yaratıcı drama "bireylerin doğaçlama, rol oynama vb. tiyatro ve yaratıcı drama tekniklerinden yararlanarak bir grup çalışması içinde bir yaşantıyı, bir olayı, bir düşünceyi, bir eğitim ünitesini kimi zaman da soyut bir kavramı eski bilişsel örüntülerin yeniden düzenlenmesi yoluyla deneyim, gözlem ve yaşantıların gözden geçirildiği "oyunsu" süreçlerde anlamlandırması, canlandırması" (San,1996) şeklinde tanımlanmaktadır. Yaratıcı dramada rol oynama, doğaçlama teknikleri sıklıkla kullanılmaktadır. Rol oynarken insan çevresinde gördügünü, örtük olarak kendi yaşantısını oynar. Bunun için yaratıcı drama velilerin kendisinin ve çevresinde tanık olduğu cinsiyet rollerini gösterme firsatı verir.

Yetişkinler görevlerini daha iyi yapmalarına katkı sağlayacak ya da kendi yaşamlarında karşılaştıkları sorunlara çözüm getirecek öğrenmelere ilgi duyarlar (Atauz, Kardam, Saktanber ve Yalın 1999). Yetişkinlerle cinsiyet ayrımcılığı konusunun yaratıcı drama yöntemi ile işlenmesi bu noktada yani yetişkinlerin görevlerini daha iyi yapmaları hususunda katkı sağlayacaktır. Cinsiyet ayrımcıl lğını önleyici doğru anne baba tutumlarını içselleştirmelerinin ve yaşamlarında uygulamalarının yaratıcı drama yöntemi ile daha etkili olacağı düşünülmektedir. Dolayısıyla yaratıcı drama yönteminin cinsiyet ayrımcıllğı bilincini geliştirmede etkili bir yöntem olacağı düşünülmüştür. 
Boyd'un yapmış olduğu bir araştırmaya göre (Akt., Adıgüzel,1994) dramanın cinsiyet kalıplarını değiştirmede firsatlar sunduğu ve cinsel rollere karşı geleneksel tavırlarının değiştirebildiği gözlenmiştir. Öğretim yöntemi olarak yaratıcı drama etkin, etkili bir grup çalışmasıdır. İletişim, etkileşim olgusu, yaşayarak yaparak öğrenme süreci, kendini tanıma, karşısındakini tanıma, birbirini anlama, doğaçlama ve yaratma gibi özellikleri vardır. Bu yönü ile yaratıcı dramanın sosyal yaşama destek sağlayıp anne baba tutumlarını da etkileyip değiştirebilecek güçte olduğu düşünülmektedir.

Yetişkinler zihinlerini yeni fikirlere, yeni algılara ve seçenekli düşünme biçimlerine kapatma eğiliminde olurlar ve yerleşmiş alışkanlıklara, kalıp düşüncelere sahip olmaya başlarlar. Kendi kişisel deneyimleriyle elde ettikleri bilgilere aşırı derecede güvenirler. Bu nedenle yetişkinler daha az açık fikirlidirler. Geçmiş öğrenmelerine ters düşen öğrenme yaşantılarını reddederler. Davranış değişikliklerine direnirler (Atauz, ve diğ., 1999). Bu nedenle yaratıcı dramanın yetişkin eğitiminde kullanılması, bireylerin kendi yaşantı ve bilgi birikimlerinden hareket etmesi nedeni ile yukarıda bahsedilen zorlukları aşmada etkili bir yöntem olacağı düşünülmektedir.

\section{Amaç}

Bu araştırmanın amacı çocukları ilköğretime devam eden bir grup annenin toplumsal cinsiyet algısını geliştirmede yaratıcı dramanın etkililiğini belirlemektir.

\section{Araştırmanın Yöntemi}

$\mathrm{Bu}$ araştırma, çocukları ilköğretime devam eden bir grup annenin toplumsal cinsiyet algısını geliştirmede yaratıcı dramanın etkisini belirlemeyi amaçlayan nitel ve nicel verilerin birlikte kullanıldığ 1 bir çalışmadır. Son yıllarda nitel ve nicel verilerin bir arada kullanılması konusunda bir görüş birliği bulunmaktadır (Acar, 2004). Yıldırım ve Şimşek (2000), nitel yöntemlerle toplanan verilerde sayıların değil, konuyla ilgili gerçekçi bir resim ortaya koymanın önemli olduğunu vurgularken, görüşmelere katılan bireylerin ifade ettikleri görüşleri okura doğrudan sunmanın gereğine işaret etmektedir. Punch (2006) nitel araştırma raporlarının büyük oranda betimleme ve yorumlamaya dayanan serbest üsluba sahip olması gerektiğini belirtmiştir.

Araştırma ön-test, son-test kontrol gruplu karışık (split-plot) desenin kullanıldığ1 deneysel bir çalışmadır. Araştırmanın bağımsız değişkeni “yaratıcı drama programı”, bağımlı değişkeni de annelerin "Toplumsal Cinsiyet Alg1 Ölçeği” ile ölçülen cinsiyet rolü alg1 düzeyleridir.

\section{İşlem}

Deney grubu annelerine her biri 120 dakika süren 12 oturum boyunca yaratıcı drama eğitim programı uygulanmıştır. Bu programda; velilerin oturumlar sırasında, iletişim ve iletişim kalıplarını görme, kendini tanıma, toplumsal cinsiyet rollerini algılama, toplumsal cinsiyet kalıp yargıların farkına varma, cinsiyet ayrımcılığının olası sonuçlarını öğrenme, kamusal alan özel alan farkına varma, medyanın toplumsal cinsiyet rolü üzerindeki etkisini anlama gibi konular ele alınmıştır. Kontrol grubuna yönelik olarak araştırmacılar tarafından herhangi bir uygulama gerçekleştirilmemiştir. Deney ve kontrol gruplarına eğitim programı öncesi ve sonrasında Toplumsal Cinsiyet Algısı Ölçeği (TCAÖ) uygulanmıştır. Deneysel bir araştırma niteliği taşıyan araştırmanın deseni Tablo 1'de verilmiştir. 


\begin{tabular}{lccc}
\hline Gruplar & Ön Testler & Denel İşlem & Son Testler \\
\hline Deney Grubu & TCAÖ 1 & Yaratıcı drama uygulaması & TCAÖ 2 \\
Kontrol Grubu & TCAÖ 3 & $\ldots \ldots \ldots \ldots . . . .$. & TCAÖ 4 \\
\hline
\end{tabular}

Yaratıcı drama grubu olarak yapılan bu çalışma, amaç bakımından bilgilenme, farkındalık, sosyalleşme ve davranış değişiminin hedeflendiği sosyalleştirici grup olduğu söylenebilir. Her grup toplantısı 1sınma, canlandırma ve değerlendirme olmak üzere üç aşamada gerçekleştirilmiştir (Adıgüzel, 2006). Isınma aşaması annelerin ilgi ve isteklerini dikkate alan hareket ve oyunları içermiş, kadınları grup sürecine ve o günkü oturumun konusuna hazırlamamıştır. Ayrıca bazı oyun ve etkinliklerden sonra oyun ve etkinliğin amacına yönelik ara değerlendirmeler yapılmıştır kadınlardan geri bildirimler alınmıştır. Canlandırma aşamasında o günkü konu çerçevesinde yaratıcı drama tekniklerinin işe koşulduğu rol oyunları, doğaçlama ve canlandırmalar yapılmıştır. Değerlendirme aşamasında, o toplantıda ne yapıldığını ve birey olarak grup üyelerinin o toplantıda ne öğrendiklerini içermektedir. Sözel paylaşımlar olabildiği gibi, yazılı etkinlikler yoluyla da paylaşımlar yapılmıştır. Ayrıca o günkü konu çerçevesinde grup lideri tarafından önceden hazırlanan sorular annelere yöneltilmiştir.

\section{Araştırmanın Çalışma Grubu}

Araştırma Ankara İli, Çankaya İlçesi, bir ilköğretim okulunda ${ }^{1}$ çocukları öğrenim gören annelerle yürütülmüştür. Bu okuldaki 16 öğrenci annesi deney grubunu, 16 öğrenci annesi de kontrol grubu olarak seçilmiştir. Annelerin gönüllü olarak çalışmaya katılmaları dikkate alınmıştır. Annelerin hepsi kadındır. Çocukları, aynı okula devam etmektedir. Bu nedenle araştırmada grup toplantıları kadınların okula gelebilecekleri saatler düşünülerek planlanmış ve gerektiğinde toplantı saati ve günlerinde değişikliğe gidilmiştir. Grup toplantıları genellikle her salı saat 14.00-16.00 saatleri arasında yapılmıştır.

Deney grubuna katılan 16 kadından, 14'ü evlidir. Bir kadının eşi ölmüş, bir kadın da boşanmıştır. Kontrol grubunda bulunan 16 kadından, 15 'i evli biri de boşanmıştır. Deney ve kontrol grubuna katılan kadınların benzer yaş aralıklarında olduğu gözlenmiştir.

Eğitim durumlarına bakıldığında iki grup arasında yine benzer bir dağılım görülmektedir. Deney grubunda üç kadın ilkokul mezunu, üç kadın ortaokul ve 8 kadının lise mezunu ve iki kadının üniversite mezunudur. Kontrol grubunda dört kadın ilkokul mezunu, altı kadın ortaokul beş kadın lise ve bir kadın üniversite mezunudur. Grup üyeleri, orta, üst sosyo ekonomik düzeyde bölgelerde ikamet etmektedirler.

\section{Veri Toplama Araçları}

$\mathrm{Bu}$ araştırmanın verileri Altınova (2009) tarafından geliştirilen Toplumsal Cinsiyet Algısı Ölçeğinden elde edilmiştir.

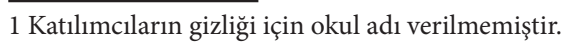


Toplumsal Cinsiyet Algısı Ölçeği: Altınova (2009) tarafından geliştirilen ölçek 30 ifadeden oluşmaktadır. Ölçek kişilerin toplumsal cinsiyet rollerini nasıl algıladıklarını belirlemek amacıyla geliştirilmiştir. Ölçeğin yapı geçerliğini belirlemek amacıyla açımlayıcı faktör analizi (döndürülmüş) yapılmıştır. Faktör analizi ile ölçeğin, ölçmek istediği yapıyı ölçüp ölçmediği belirlenmeye çalışılmıştır. Faktör analizine alınan değişkenlerin (maddelerin) kaç faktörde toplandığını belirlemek amacıyla öncelikle özdeğerlere (Eigenvalue) ve açıklanan yüzdelere bakılmıştır. Elde edilen bu sonuçlar TCA Ölçeği'nin dört boyutlu olduğuna işaret etmektedir. Bu boyutlar 1. Alt boyut: Erkeğin Üstünlüğünü Kabul Cronbach $\alpha=0.791,2$. Alt Boyut: Eşitlik İsteme Cronbach $\alpha=0.735,3$. Alt Boyut Çalışma Hayatına Girme İsteği Cronbach $\alpha=0.6814$. Alt Boyut: Kamusal Görevler Üslenme İsteği Cronbach $\alpha=0,676$. Bu sonuç, ölçeğin geçerliği için kanıt olarak değerlendirilmiştir. Ölçekte 2, 3, 5, 7, 10, 11, 12, 14, 17, 18, 19, 21, 22, 24. 26. 29. 30. maddeler ters çevrilerek hesaplanmıştır. Buna göre, ölçekten alınabilecek puanlar 30-150 aralığında olup, yüksek puanlar toplumsal cinsiyet algısının olumlu olduğunu ifade etmektedir.

\section{Verilerin Çözümlenmesi}

Deney ve kontrol grubuna uygulanan toplumsal cinsiyet algısı ölçeğinden elde edilen sonuçlara dayalı olarak, her iki grubun ön-test ve son- test puanlarının ortalamaları ve standart sapmaları belirlenmiştir. Deney ve kontrol grubunun denk olup olmadığını belirlemek amacıyla deney ve kontrol grubunun ön-test puanlarının ortalamaları arasındaki farkın anlamlılığı "t testi" ile test edilmiştir.

Açık uçlu sorulardan oluşan görüşme formu kullanılmıştır. Bu form ile uygulamaya ilişkin öğrenci ve öğretmen görüşleri belirlenmiş ve elde edilen veriler üzerinde içerik analizi yapılmıştır.

\section{Bulgular ve Yorum}

Araştırma sonunda elde edilen bulgular tablo 2, 3 ve 4 şeklinde düzenlenmiş ve buna ilişkin yorumlar aşağıda verilmiştir.

Toplumsal cinsiyet algısı ölçeğinden elde edilen verilerin betimsel istatistikleri aşağıda verilmiştir.

Tablo 2.Deney ve Kontrol Gruplarının Betimsel Ístatistikleri

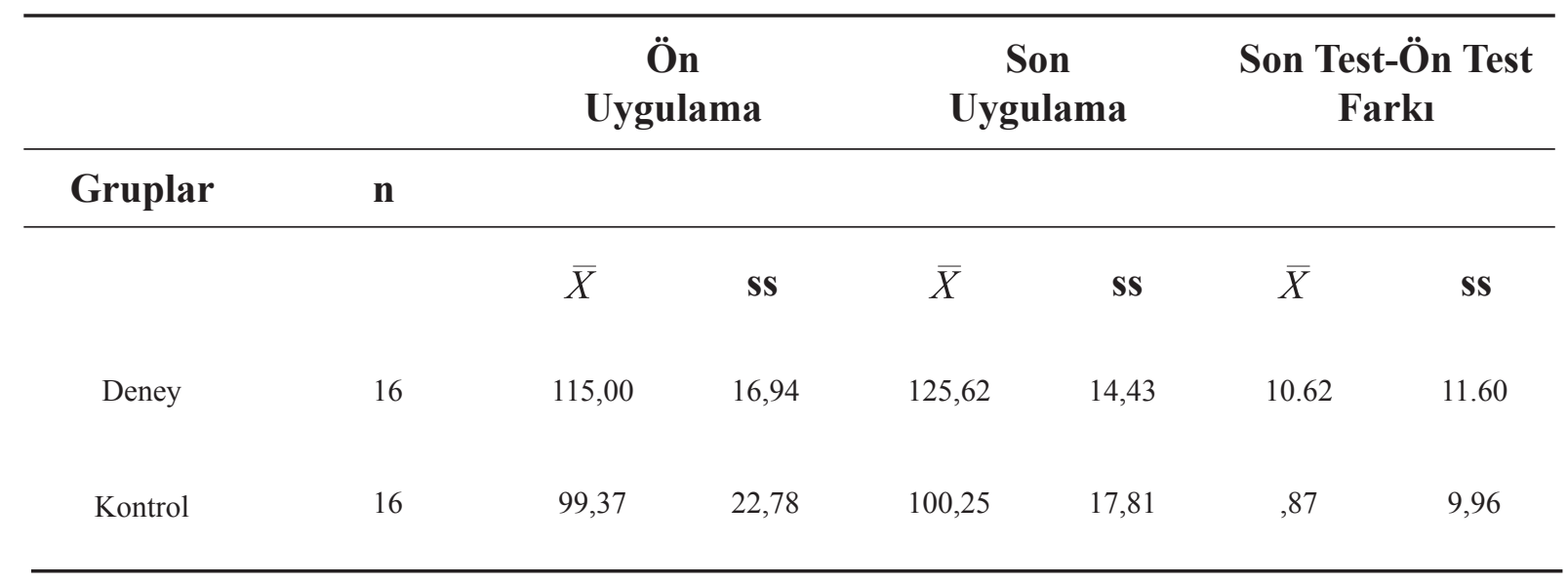


Tablo 2'de görüldüğü gibi toplumsal cinsiyet algıs1 ölçeğinin ön uygulaması sonucunda deney grubu 115,00 kontrol grubu ise 99,37 ortalamaya ulaşmıştır. Çalışma sonucunda ise deney grubu 125,62 kontrol grubu ise 100,25 ortalama puan almıştır. Toplumsal cinsiyet algıs1 puanların son test ön test arasındaki farka bakıldığında deney grubunda 10,62 puanlık bir artış, kontrol grubunda ise 0,87 puanlık bir artış görülmüştür. Deney grubunda yapılan etkinliklerin annelerin başarılarını arttırdığı görülmektedir. Bu farklılıkların istatistiksel olarak anlamlı olup olmadığına ilişkin karşılaştırmalı istatistikler sırayla aşağıda verilmiştir. Deney ve kontrol gruplarının karşılaştırılmasında anlamlılık düzeyi 0,05 olarak kabul edilmiştir.

\section{Uygulama öncesi deney ve kontrol grubunun karşılaştırılması}

Grupların denk olup olmadığını belirlemek amacıyla ön test puanları arasındaki farkın anlamlı olup olmadığı bağımsız gruplar arası "t testi" ile test edilmiştir.

Tablo 3.Deney ve Kontrol Grubunun Ön Test Puanlarının Karşılaştırılması

\begin{tabular}{lcccccc}
\hline Gruplar & $\mathbf{n}$ & $\bar{X}$ & SS & sd & t & p \\
\hline Deney Grubu & 16 & 155,00 & 16,94 & & & \\
Kontrol Grubu & 16 & 99,37 & 22,78 & & 2,070 & \\
\hline
\end{tabular}

Tablo 2 incelendiğinde deney ve kontrol grubu velilerinin ön test puan ortalamaları arasında istatistiksel olarak anlamlı farkın olmadığ 1 görülmüştür $(p=, 056)$. Bu durumda deney ve kontrol grubu annelerin uygulama öncesinde toplumsal cinsiyet algılarının benzer olduğu belirlenmiştir. Bir başka ifadeyle deney ve kontrol grubu annelerin çalışmalara benzer düzeyde başladığı söylenebilir.

\section{Uygulamanın gruplar içi değerlendirilmesi}

Uygulama sonrası gruplar arasında fark olup olmadığını belirlemek amacıyla bağımlı gruplar aras1 "t testi" ile test edilmiştir.

Tablo 4.Deney Grubunun Test Puanlarının Karşılaştırılması

\begin{tabular}{|c|c|c|c|c|c|c|c|c|}
\hline Ölçümler & & n & $\bar{X}$ & ss & sd & $\mathbf{r}$ & $\mathbf{t}$ & $\mathbf{p}$ \\
\hline \multirow[b]{2}{*}{ Deney } & Ön test & 16 & 115,00 & 16,94 & & & & \\
\hline & Son test & 16 & 125,62 & 14,43 & 11,60 & ,737 & $-3,663$ &, 002 \\
\hline \multirow[t]{2}{*}{ Kontrol } & Ön test & 16 & 99,37 & 22,78 & & & & \\
\hline & Son test & 16 & 100,25 & 17,81 & 9,96 & ,908 &,- 351 &, 730 \\
\hline
\end{tabular}


Tablo 4'te görüldüğü gibi ön uygulamada 115,00 olan puan ortalaması uygulama sonrasında 125,62 'ye çıkmıştır. Annelerin ön test ve son test toplumsal cinsiyet rolü algısı puan ortalamaları arasında son test lehine istatistiksel olarak anlamlı fark bulunmuştur $(p=, 002)$. Bu durum yaratıcı drama çalışmasının annelerin cinsiyet rolü algı düzeylerini geliştirdiği göstermektedir.

Tablo 4'te görüldügü gibi ön uygulamada 99,37 olan puan ortalaması uygulama sonrasında 100,25 'e çıkmıştır. Annelerin ön test ve son test cinsiyet rolü algısı ölçeği puan ortalamaları arasında son test lehine istatistiksel olarak anlamlı fark bulunmamıştır $(p=, 730)$. Bu durum yaratıcı drama çalışmasına katılmayan annelerde cinsiyet rolü algı düzeylerinin aynı kaldığını göstermektedir.

Deney ve kontrol grubunun toplumsal cinsiyet rolü algısı son test-ön test puanları arasındaki fark ortalamalarının birbirinden anlamlı derecede farklılaşıp farklılaşmadığını belirlemek için bağımsız örneklemler arası "t testi” yapılmıştır. Yapılan bu karşılaştırmadan elde edilen bulgular Tablo 5'te verilmiştir.

\section{Uygulama sonrası deney ve kontrol grubunun karşılaştırılması}

Tablo 5.Deney ve Kontrol Grubunun Son-Ön Test Puanları Arasındaki Farkın Karşılaştırılması

\begin{tabular}{lcccccc}
\hline Gruplar & $\mathbf{n}$ & $\bar{X}$ & Ss & sd & t & p \\
\hline Deney Grubu & 16 & 10,62 & 11,60 & 9,75 & 2,55 &, 016 \\
Kontrol Grubu & 16 & 0,87 & 9,96 & & & \\
\hline
\end{tabular}

Tablo 5’te görüldüğü gibi toplumsal cinsiyet ölçeği puan artışı ortalamaları deney grubunda 10,62 iken kontrol grubunda 0,87 olarak belirlenmiştir. Karşlaştırma sonunda toplumsal cinsiyet puanları arasındaki farkın istatistiksel olarak deney grubu lehine anlamlı olduğu gözlenmiştir $(\mathrm{p}=, 016)$. Deneyin etkililiğin belirlendiği bu bölümde deney ve kontrol grubu toplumsal cinsiyet rolü algısı puanları arasındaki farktan yola çıkarak deney grubunda uygulanan yaratıcı darama etkinliklerinin velilerin cinsiyet rolü algısını artırmada etkili olduğu görülmüştür.

\section{Velilerinin cinsiyet ayrımcılığına iliş̧kin görüşleri.}

Annelerle yapılan görüşmelerden elde edilen sonuçların içerik analizi ile meslek seçme, kadın olmak erkek olmak, kız çocuklarına ve erkek çocuklara izin, kız ve erkek çocuklara farklı davranma dört tema oluşturulmuştur.

\section{Sınıf kadın ve erkeklerin hangi meslekleri seçmeleri ile ilgili olarak,}

Deney öncesinde kuzlar "öğretmen, hemşire, memur, avukat, eczacl, halkla ilişsiler uzmanı" yazıldığı görülmüş̧ür. Deney sonrasında "öğretmen, hemşire, memur, avukat, eczacl, halkla ilişkiler uzmanı, mühendis, güzel sanatlar, işveren, polis, mimar" yazıldığı görülmüş̧ür.

Deneyöncesinde erkekler "doktor, mühendis, polis", deney sonrasinda da "doktor, mühendis, polis” yazıldığı görülmüştür.

$\mathrm{Bu}$ sonuç annelerin toplumda kadına ve erkeğe uygun görülen, atfedilen meslekleri yazmayı tercih ettiklerini göstermektedir. Eğitimden sonra kadına özgü mesleklerin sinırlarını genişlettikleri gözlemlenmiştir. 


\section{Erkek çocuklar ile kız çocuklar arasındaki farklııklarla ilgili olarak,}

Eğitim öncesinde "erkek çocukların daha hareketli, sorumsuz ve yaramaz, kız çocuklarının daha sakin, sorumluluk sahibi ve uysal oldukları yazılmıştır.

Bu sonuç toplumsal hayatta kızlardan sakin, sorumluk sahibi ve uysal olmaları, erkeklerden hareketli, özgürlüğüne düşkün, atılgan olmaları yönündeki öğretilerle paralellik göstermektedir.

Eğitimden sonra kızlar ile erkekler arasında biyolojik farktan başka bir fark olmadığı görüşü hâkim olmuştur.

Bu da toplumsal cinsiyetin sonradan kurgulanmış olduğu yönünde bir bilinç geliştirdiklerini göstermektedir.

\section{Kız ve erkek çocuklarına dışarı çıkma izni verilmesiyle ilgili olarak,}

Eğitimden önce kız çocuklarına belirli bir saatte eve dönmesi tembih edilerek, telefonla sık sık aranarak, güvenilir arkadaşlara gitmesi şartı ile izin verildiği belirtilmiş.

Erkek çocuklarına ise gittiği yeri söylemek ve telefonunu yanına almak şartı ile izin verildiği yazılmıştır.

Kız çocuklarının dışarı çıkma şartlarının daha ağırlaştırıldığı ve daha katı kurallarla belirlendiği, erkek çocuklarına daha esnek davranıldığı sonucuna varılmıştır.

\section{Kız ve erkek çocuklarına farklı davranılıp davranılmadığıyla ilgili olarak,}

Kız çocukların ev odaklı anneye yardım etmesi gereken bireyler olarak yetiştirildiği, kızlara korumacı yaklaşıldığ 1 , erkeklerin dışarı odaklı ve özgür yetiştirildiği cevaplarda yazılmıştır. Kız ve erkek çocuklarına farklı davranıldığı, geleneksel ataerkil tutumların sergilendiği sonucuna ulaşılmıştır.

Eğitimden sonra durumun artık yavaş yavaş günümüzde değiştiği ve değişmesi gerektiği belirtilmiştir.

\section{Cinsiyetinizden dolayı ayrımcılığa uğrayıp uğramadığıyla ilgili olarak,}

Dokuz kişi hayır cevabını vermiş, bir kişi ben kadın olduğumun farkındayım bu nedenle biraz geride durmam gerekir cevabı ile gerekçelendirmiştir. İki kişi bazen, bir kişi maalesef, dört kişi evet cevabını vermiştir. Bu soruya üstü kapalı hayır dendiği düşünülmektir. Oturumlar başladıktan sonra katılımcıların çoğunun aslında ayrımcı tutumlar ile büyütüldü̈g̈̈ kendi ifadeleri ile belirlenmiştir.

Son testte ben kadınım biraz geride durmam gerekir diyen katılımcı yerine göre erkeğin de geri de durarak uzlaşması gerektiğini belirtmiştir

Deney grubu ile kontrol grubu karşılaştırıldığında ön testlerinde anlamlı bir farklılık gözlenmezken son testlerinde, kontrol grubunda cinsiyetçi tutumların varlığı (kızlar uysal, hanım hanımcık olmalı, erkekler hareketli, özgür olmalı vb.) gözlemlenmiştir. Deney grubunda anlamlı değişikliklerin olduğu, kız çocuk ile erkek çocuk arasında sadece biyolojik farkların olduğu, eşit şartların verilmesi gerektiği belirtilmiştir.

Katılımcı grubunu eğitimleri lise ve üniversite düzeyinde, ilgili, eğitime bakış açıları ilerici, bilinçli aile tutumlarına sahip olmalarına rağmen bu oturumda, farkında olmadan yaptıkları ayrımcı tutumları gördüler ve bunu paylaştılar. Bazen bilerek bazen bilmeden çocukların meraklarını törpülediklerini, kız çocukların önlerindeki seçenekleri, imkânları sınırladıklarını, ayıpladıklarını, farklı cinsiyette ki çocuklardan farklı isteklerde bulunduklarını hissettiler. 


\section{Sonuç ve Öneriler}

$\mathrm{Bu}$ araştırmada yaratıcı drama uygulamasının çocukları ilköğretime devam eden annelerin toplumsal cinsiyet algısına etkisi araştırılmıştır. Bu çerçevede toplumsal cinsiyet algısını geliştirmeye yönelik yaratıcı drama programı geliştirilmiş ve uygulanmıştır. Araştırma sonucunda elde edilen bulgular, yaratıcı drama uygulamasının annelerin toplumsal cinsiyet algısı üzerinde etkisi olduğunu göstermiştir. Yaratıcı drama grup çalışmasına katılan annelerin toplumsal cinsiyet algı düzeyleri, gruba katılmayan annelere oranla anlamlı bir artış göstermiştir. Bu sonuç toplumsal cinsiyet algısının yaratıcı drama yoluyla artış gösterebileceği sonuçları ile uyumludur (Altınova, 2006; Dereboy ve diğ., 2005; Mete ve Gerçek, 2005; 2005; Salmon, 2003; Tarrant ve diğ., 2009).

Yaratıcı dramaya katılanlar kurgusal olarak başkasının rolüne girer, roldeki o insanmış gibi davranır ve onun dünyasına anlar. Böylelikle başkalarının duygusal, psikolojik hayatlarını daha iyi kavrayabilirler. Bu çalışmada da kadınlar birbirinden farklı pek çok role girip çıkmışlardır. Bazen çalışan kadın, bazen baba, bazen anne, bazen sokaktaki kadın olmuşlardır. Kadınlar her bir konunun farklı yönleriyle karşılaşmışlardır. Yaratıcı drama etkinlikleri içerisinde sıkça kullanılan canlandırmalar ve gerçek hayatla olan bağlantıları, yaşantımızdaki yeri üzerinde konuşulmuştur. Dolayısıyla hayatlarında karşılaşabilecekleri pek çok durumu tanıma firsatı da bulmuşlardır. Boyd'un da belirttiği gibi (Akt., Adıgüzel,1994) yaratıcı drama cinsiyet kalıplarını değiştirmede firsatlar sunar ve cinsel rollere karşı geleneksel tavırlarının değişebilir.

Toplumsal cinsiyet eşitliği ve kadının güçlendirilmesinin başarılması için sağlık, eğitim ve istihdam alanlarındaki tüm politika ve programların geliştirilmesi, uygulanması, izlenmesi ve değerlendirilmesinde gerekmektedir. Kadın olmak pek çok problemi beraberinde getirmektedir. Geleneksel cinsiyet rolleri, kadınlar için olumsuz sonuçlar yaratmaktadır. Bu olumsuz sonuçlar, insanların kendilerini gerçekleştirmelerine, mutlu olmalarına engel olmaktadır. Mutlu, anlamlı, bir yaşam için insanların kendilerini istedikleri gibi biçimlendirmelerine izin verilmelidir. Bunun için de özellikle kadınların psikolojik, ekonomik, siyasal ve eğitim açısından güçlendirilmeleri gerekmektedir.

Araştırmadan elde edilen sonuçlar göz önüne alınırsa özellikle okullarda, Toplum Merkezlerinde, Halk Eğitim Merkezlerinde eğitimler yapılması sağlanmalıdır. Böylece buradaki kadınlarla, kadınlara yönelik toplumsal cinsiyet eşitsizliği ve ayrımcılığı hakkında farkındalık kazandırılabilir. Toplumsal cinsiyet ayrımcılı̆̆ını daha fazla yaşayan kadınlara ulaşma kolaylığı daha fazla olan Sosyal Hizmet Uzmanı, Psikolojik Danışman ve Rehber Öğretmen, konuyla ilgili Yaratıcı Drama Liderleri bu sonuçları kullanabilir. Onların toplumu bu konuda bilinçlendirmede savunuculuk, liderlik, eğitim ve danışmanlık rolleri vazgeçilmezdir.

\section{Kaynaklar}

Acar, G. (2004). Beden emek tarih: diyalektik bir feminizm için. Kanat Yayınları, İstanbul.Acker, J. (1992). From sex roles to gender edinstitutions. Contemporary Sociology, Vol. 21, No: 5

Altınova, H.H. (2009). Yaratıcı drama yönteminin kadınların özsaygı düzeyine ve toplumsal cinsiyet bilincine etkisi. Yayınlanmamış Yüksek Lisans Tezi, Ankara Üniversitesi Eğitim Bilimleri Enstitüsü, Ankara.

Arslan, A. (2003). Eşitsizliğin teorik temelleri: Etik teorisi. Kocaeli Üniversitesi Sosyal Bilimler Enstitüsü Dergisi, 6 (2), 115-135.

Atauz, A.,Kardam, F.,Saktanber, A. ve Yalın, H.İ. ( 1999) . Toplumsal cinsiyet eğitimi el kitabı. Kadın İstihdamını Geliştirme Projesi T.C Başbakanlık Kadının Statüsü ve Sorunları Genel Müdürlüğü

Cherry, A. L. (2005). Examining global social welfare issues. ThomsonBrooks/Cole, Belmont. 
Demirbilek, S. (2007). Cinsiyet ayrımcilığın sosyolojik açıdan incelenmesi. Finans Politik ve Ekonomik Yorumlar Dergisi, 44 (511), 45-49.

Ensher, E.A., Grant-vallone, E.J. and Donaldson, S.I. (2001). Effects of perceived discrimination on job satisfaction, organizational commitment, organizational citizenship behavior, andgrievances", Human Resource Development Quarterly, 12: 56-58.

Eren, A. (2005). Korku kültürü, değerler kültürü ve şiddet. Aile ve Toplum. Eğitim-Kültür ve Araşstrma Dergisi, 2 (8), 23-37

Esen, Y. (2002). İlköğretim ders kitaplarındaki kadın ve erkek resimlerine ilişkin bir inceleme. Ankara Üniversitesi Eğitim Bilimleri Fakültesi Dergisi, 35 (1-2) 143-154.

Gender Discrimination. (Erişim: http://worldnet.scout.org/scoutpax/en/8/8_genderdiscrimination_en, 08.09.2007)

GenderEquality: PracticeNote, November 2002. (Erişim: http://www.undp.org/policy/docs/ policynotes/ gender-9dec02. doc, 07.09.2007).

Goodman, J.S.;Fields, D. ve Blum, T. (2003). Cracks in theglassceiling. Group-Organization Manage ment, 28(4), 475-501

Foley, S.,Hang-Yue, N. andLo1, R.(2004). Antecedents and consequences of perceived genderdiscrimi nation: a social identityperspective. Asia Pacific Journal of Management, 1-30.

Hablemitoğlu, Ș. (2005). Toplumsal cinsiyet yazıları. (İkinci Bask1, sy. 20-40). İstanbul: Toplumsal Dönüşüm Yayınları.

Human Rights and Equal OpportunityCommision, 2006. (Erişim: www.humanrights.gov.au, 17.08.2007)

Jones, Melinda (2002); Social Psychology of Prejudice, PearsonEducation, New Jersey.

Kitiş, Y., ve Bilgici, S. Ş. (2007). Bir aile içi şiddet olgusu: Sur tutma ilkesi ile şiddeti ihbar etme yükümlülüğü arasındaki etik ikilem. Aile ve Toplum. Eğitim-Kültür ve Arasttırma Dergisi, 3 (11), 7-13.

Lockwood, R. (2004). Domesticandinternationalperpectives. ResearchQuarterly, Ocak Saylsi, 1-10

Lopez-Claros, A. ve Zahidi, S. (2005). Women's empoverment: measuring the globalgendergap. Har vard Business Review Özel Raporu.

Markham, U. (1999). Bask altındaki kadın. Birinci Basım, Ankara, ALFA Basım Yayım Dağıtım.

Marshall, G. (1999); Sosyoloji sözlüğ̈̈, (Çev.: Osman Akınhay/Derya Kömürcü), Bilim ve Sanat Yayınları, Ankara.

Martı, P.Y. (May 2006). Practising gender at work: furtherthoughts on reflexivity. Gender, Work and Organization, Vol. 13, Issue: 3.

Parlaktuna, İ,(2010). Türkiye'de cinsiyete dayalı mesleki ayrımcılığın analizi. Ege Akademik Bakış Dergisi, Cilt: 10 Sayl: 4 Ekim 2010 ss. 1217 - 1230

Parrillo, V. N. (2002). Contemporary social problems. Fifth Edition, Allynand Bacon, Boston. 
Savc1, İ. (1999). Toplumsal cinsiyet ve teknoloji. Ankara Üniversitesi Siyasal Bilgiler Fakültesi Dergisi, C. 54, Sa: 1 .

Seyyar, A. (2002); Sosyal Siyaset Terimleri. Beta Basım Yayım, İstanbul.

Sullivan, T. J. (2003); Introduction to social problems. Sixth Edition, PearsonEducation, Boston.

Tan, M. (1979). Kadın: Ekonomik yaşamı ve eğitimi. Ankara: Türkiye İş Bankası Yayınları.

Ünal, I. (2003). İlköğretim okullarında demokratik okul ortamının oluşturulmasına kadın yöneticilerin katkısı. Eğitim Bilim Toplum Dergisi, Bahar- Yaz sayısı, 29-35

Zanden, J. W. Vander (1993); Sociology: Thecore. Third Edition, McGraw-Hill, New York.

Yoder, J. D. (2003); Women and gender. Transforming Psychology, Second Edition, Prentice Hall, New Jersey. 


\section{Summary \\ Effect Of Creative Drama Group Work Method To Gender Discrimination}

\author{
Hüseyin ALTINOVA ${ }^{1}$ \\ Ankara University
}

\author{
Hülya ALTINIŞIK ${ }^{2}$ \\ Ministery of Education
}

Discrimination is defined as to conduct negative action against a group of people for being the members of that group (Zanden, 1993; Jones, 2000). In general gender discrimination is to behave unfairly towards individuals because of their gender (GenderDiscrimination, http:// worldnet.scout.org). Gender discrimination is being subjected to discrimination, exclusion or restriction based on norms and gender roles which prevent person's full use of human rights (GenderandReproductiveRights, www.who.int). Gender discrimination can be divided into two as direct and indirect gender discrimination. Women were subjected to gender discrimination and inequality throughout the history. They were considered to have lower status than men and they had less rights and chances than men. Even though there are some improvements about this issue in some countries, still women are being subjected to discrimination, sexual abuse and domestic violence. It's no doubt, mostly because of socialization by which traditional gender roles are learnt. Adults are interested in educations which help them to fulfill their duties in a better way or to solve problems of their lives (Atauz, Kardam, Saktanber, Yalın, 1999). To educate adults about gender discrimination by creative drama method will help them to fulfill their duties in a better way. It's thought that internalizing and conducting right parenthood attitudes which prevent gender discrimination is more effective by using creative drama method. Therefore it is considered that creative drama method will be an effective method for cultivating gender discrimination awareness.

\section{Objectives}

The goal of this research is to define the effectiveness of creative drama to improve gender discrimination awareness of group of parents whose children are in primary school.

\section{Research Method}

This is a research used qualitative and quantitative data in order to define the effectiveness of creative drama to improve gender discrimination awareness of group of parents whose children are in primary school. It is an experimental study of using pretest-posttest control group in mixed split-plot design. The independent variable is "creative drama program" and dependent variable is level of gender role perceptions of the parents whose perceptions are measured by "Gender Perception Scale".

\section{Process}

The creative drama program is conducted on experimental group of parents for 12 sessions which last 120 minutes each. In this program, the subjects of communication and communication patterns, knowing oneself, perception of gender roles, being aware of stereotyped gender roles, learning of possible results of gender discrimination, being aware of public/private sphere, and understanding of media's effect on gender roles are discussed with parents. No action is conducted on control group. Gender Perception Scale is conducted on both groups before and after the program.

1 Lecturer, Ankara University Faculty of Health Scrences, Social Services Department, e-mail: altinova2012@gmail.com

2 MEB, Conselor and Guides Teacher 


\section{Study Group}

The research is conducted with the parents of students of a primary school which is located in district of Çankaya in Ankara. There are 16 parents in experimental group and 16 parents in control group.

\section{Data Collection}

Data is collected by Gender Perception Scale which is developed by Altinova (2009) and by structured interview form.

\section{Data Analysis}

Based on the results of experimental and control group from Gender Perception Scale, both groups' pretest-posttest average scores and standard deviations are calculated. In order to determine whether there is balance between experimental and control group, average scores of pretests of both groups are tested with "t test". Interview form of open ended questions is used. With that form teachers and students' views about practice are determined and content analysis is conducted on collected data.

\section{Findings and Interpretation}

There is 10,62 score raise in experimental group and 0,87 score raise in control group based on the difference between pretest and posttest. Activities conducted in experimental group seem to raise the scores.

There is not statistically meaningful difference between average pretest scores of experimental and control group $(p=, 056)$. It means that before the program both groups' perception of gender were similar.

Pretest average score was 115,00 while posttest average score is 125,62 for experimental group. According to average gender perception scores of pretest and posttest there are statistically meaningful difference in favor of posttest $(p=, 002)$. It shows that creative drama program improved the gender roles perception level of parents. Pretest average score was 99, 37 while posttest average score is 100, 25 for control group. According to average gender perception scores of pretest and posttest there aren't statistically meaningful difference in favor of posttest $(p=, 730)$. It shows that gender roles perception levels of parent who did not join creative drama program did not changed.

Gender scale average score raise in experimental group is 10, 62 while it is 0,87 in control group. In the end, the difference between gender scores of both group is statistically meaningful in favor of experimental group $(p=, 016)$.

\section{Results and Conclusion}

In this research the effect of creative drama method on gender perception of the parents whose children is in primary school is studied. In this context creative drama program for improving gender perception is developed and conducted. According to data collected from the research creative drama program improved the gender perception of parents. There is a raise in gender perception levels of experimental group compared to the parents who did not join the program. 
